\title{
Kampen for Laurids Skaus eftermæle
}

\section{Et bidrag til den_sønderjyske historieskrivnings historie}

\author{
Af $H . V$. Gregersen.
}

Den 18. maj 1893 oplevede man atter engang en af de store festdage på Skamlingsbanke. Her havde der ellers, bortset fra mindre sammenkomster, været tyst og stille $i$ alle de mange år efter ulykkerne i 1864. "Lad os tie og bie«, havde Orla Lehmann sagt i 1866," da den kendte støtte $i$ al stilhed var blevet genrejst efter sprængningen under krigen. Med sine skår var den blevet et endnu skønnere og dertil et mere sandt minde om de personer, hvis navne den brerer, thi sår og skrammer havde sat et varigt stempel på hin generation af danske sønderjyder, der havde oplevet de nationale kampes tid. Det havde derfor efter krigens tid været ret og rigtigt at tie og bie.

Men i 1893 var man nået frem til 50-året for den unge Laurids Skaus imponerende og for alle hans samtidige så forbløffende fremtræden på Skamlingsbanke. Dette minde måtte højtideligholdes, og en komité under ledelse af rigsdagsmand Gustav Johannsen havde indsamlet midler til rejsning af en speciel mindestøtte for Laurids Skau. Man kunde måske finde det noget ejendommeligt med hele to mindesmærker på samme sted for samme person, thi Laurids Skaus navn kunde jo i forvejen læses på Skamlingsbanke-støtten. Offentligt kom den slags tanker imidlertid ikke frem $\mathrm{i}$ hine tider, da den danske befolkning i Sønderjylland levede under et årelangt besættelsesstyre. Man var henvist til at drøfte enhver sag mand og mand imellem eller til at give udtryk for sine meninger $\mathrm{i}$ private breve, som følgelig ofte bliver vor eneste kilde til viden om de interne spørgsmål, der var fremme i tiden. Vi ser derfor også af et brev fra redaktør Jens Jessen, "Flensborg Avis «, fra 1898 3/1, at han havde anset det for uklogt med den lille støtte på Skamling.

Det var den betydeligste blandt Laurids Skaus brødre, gårdejer Peder Skau til Bukshave i Fjelstrup sogn, der fik denne besked. Peder Skau nærmede sig ved den tid støvets år. Under stor festivitas 


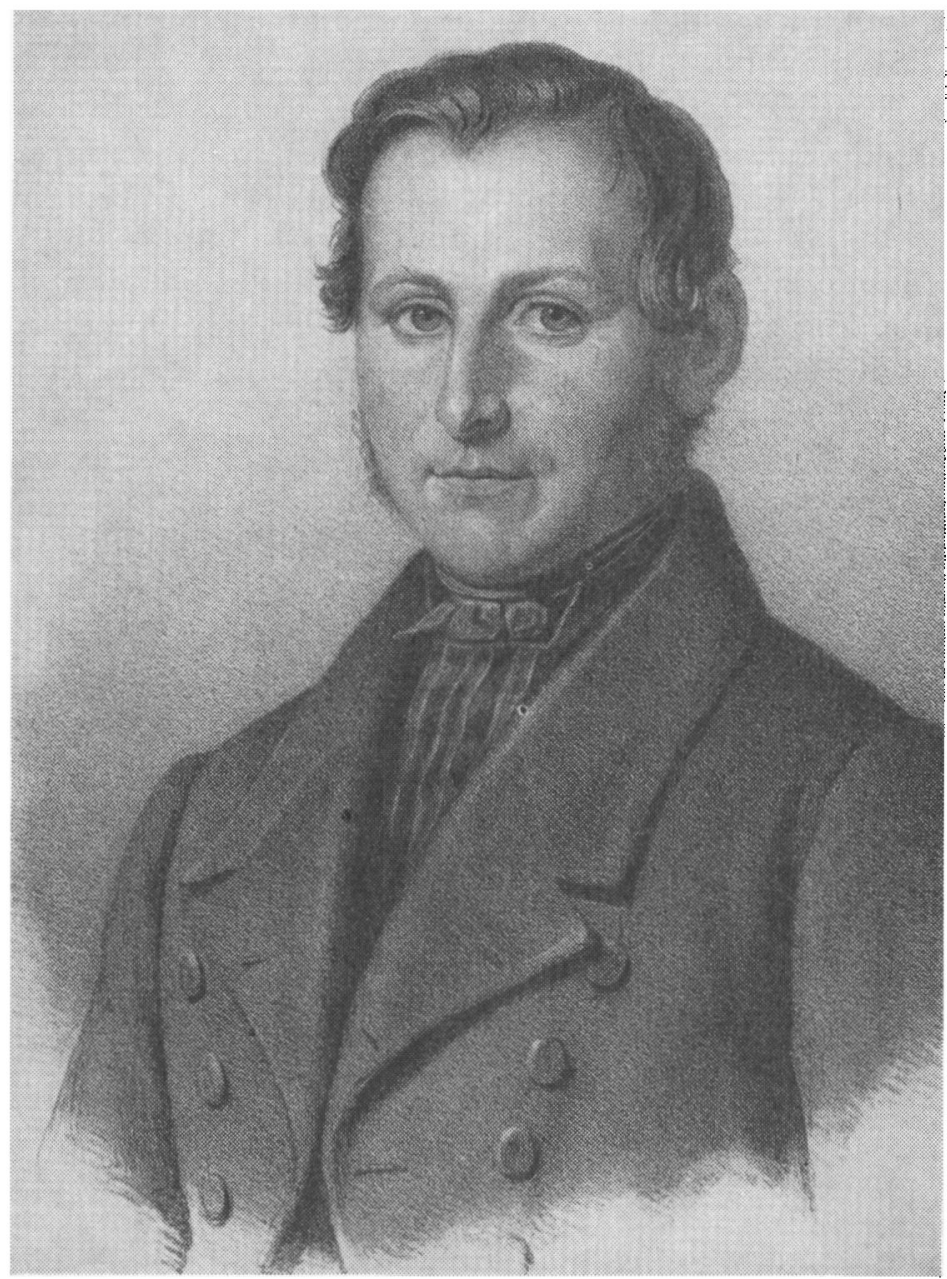

Laurids Skau, 1817-64. „Taleren ved Skamlingfesten den 4. juli 1844, Hadersbonden Laurids Skau“, således lyder teksten neden under det her viste portrat, der er fremstillet af Emil Barentzen \& Co.s lithographiske Institut til ophongning $i$ de mange hjem. - I sin begravelsestale sagde provst Kofoed-Hansen, Gl. Haderslev, bl. a.: „Han var et skud af folkets livsrod, dens inderste, et herligt skud. Der kan gå lange tider, der kan gå århundreder hen, for der udsendes et lignende“. 
blev hans 70-års dag fejret i 1895, og det har uden tvivl været ham meget kært, at han på sine gamle dage kunde være med til at sætte sin forlængst afdøde broder et æresminde. Selv havde han på mange måder levet i skyggen af sin storebror. Efter ham havde han således arvet modsætningsforholdet til Hans Andresen Krüger og til mange af Haderslev vesteramts grundtvigske bønder. En overgang havde han håbet at blive Krügers efterfølger, ${ }^{3}$ ikke mindst efter at Peter Hiort Lorenzens søn, "Dannevirke«s redaktør, Hans Rudolf HiortLorenzen, i 1878 havde set sig nødsaget til at forlade sin sønderjyske hjemstavn, men derude vesterpå tilgav man aldrig Peder Skau, at han $\mathrm{i} 1879$ havde tilladt sig at kritisere Hans Krüger $\mathrm{i}$ ret voldsomme vendinger. Krüger var for disse kredse sacrosanct, og det fih Peder Skau omgående at føle.

I et brev til H. R. Hiort-Lorenzen har han 1880 1/10 fortalt herom på denne måde: "Hvad Landdagsvalget angaaer, da havde jeg fortørnet de grundtvigianske Venstremænd forrige Sommer [altså i 1879] ved et Møde i Aabenraa i Junggreens Huus, hvor Krüger paastod, at han aldrig havde begaaet nogen Fejl og bad om at paavise en saadan. Jeg paastod da, at han havde ladet sig narre af sine Venner i Rigsdagen til at tie stille, da Ophxvelsen af $\$ \mathrm{~V}$ blev den tilkjendegivet, og dette kunde Krüger ikke tilstrækkelig modbevise. Denne Synd vilde Vesteramterne ved Hjxlp af to herfra - Finnemann og P. Viuff i Sillerup - nu hævne ved ikke at ville stemme paa mig, og saaledes kom jeg ud. Paa given Forespørgsel, hvad de havde imod mig, svarede Skrumsager, at de intet havde imod mig, men de vilde opstille en ny .

I et senere brev til H. R. Hiort-Lorenzen - 1881 18/8 - har Peder Skau gentaget denne sin opfattelse af forholdet til vesteregnens folk: "Saasnart Rigsdagsvalget er ovre, saa har vi Spørgsmaalet om Edsaflæggelsen i Deputeretk[ammeret], som H[ans] Lassen og jeg allerede forrige Aar udtalte os for i Aabenraa-Mødet, hvor jeg tillige læste $\mathrm{Kr}$ [üger] Texten, hvad der kostede mig mine Poster i Kreds- og Landdag. Jeg er dog glad ved, hvad jeg gjorte. Det er saa rart at beholde sin Selvstændighed «.

I 1886 lykkedes det atter Peder Skau at komme ind i det politiske liv som medlem af den slesvigholstenske provinslanddag, men klog af skade lod han det ikke komme til en styrkeprøve under landdagsvalget i 1888. I stedet blev Gustav Johannsen fra Flensborg Haders- 
lev-kredsens repræsentant. Også om denne sag har han fortalt H. R. Hiort-Lorenzen i et brev af 1889 6/2: "Jeg husker ikke, om jeg har skrevet til Dem efter Landdagsvalget. Jeg satte Gustav Johannsens Valg igjennem ved selv at træde tilbage. De ved, jeg har kxmpet i flere Aar for at faa Posten besat, ja maatte bøde derfor ved Tabet af mine offentlige Poster i 6 Aar, men Opreisning fik jeg, og nu, da Mindretallet var bleven til Flertal, saa syntes jeg, at det var meget kjønnere at træde tilbage end selv at plukke Frugterne. Et andet Moment laa ogsaa bagved, nemlig at vi nu har meget lettere ved at holde Gustav Johannsen i Rigsdagen, da han faaer Dixterne (15 M[ark] daglig) i Landdagen « (Gustav Johannsen var kendt for jæunligt at være i pengetrang!).

Det var efter alt dette kun naturligt, at det tilfaldt Gustav Johannsen som Haderslev-egnens repræsentant at forestå afsløringen af mindestøtten for Laurids Skau i 1893. Han udtalte ved den lejlighed følgende:" "Vi vil sætte Laurids Skau et særligt Mindesmærke, fordi han for os dernede har faaet en saa umaadelig Betydning, saa at det endnu kan kendes iblandt os. ... Vi vil sætte ham et særligt Mindesmærke, der skal tale til kommende Slægter om, at vi Sønderjyder har forstaaet Laurids Skaus store Gerning. ... Hans Minde lever i Folkets Hjerter, og Historien vil altid nævne hans Navn som en af vore bedste, om ikke den allerbedste af vore Sønner «.

Det var store ord, og selv om de var nok så ærligt ment, har der vel mellem de henved 7000 festdeltagere været dem, der i deres stille sind har tænkt, om der nu også var fuld dækning for dem. Givet er det $\mathrm{i}$ hvert fald, at den anti-skauske indstilling stadig havde grobund, især da i Haderslev vesteramt. Den kritiske indstilling over for Laurids og Peder Skau blev naturligvis ikke mildnet ved, at familien endnu samme år lod rejse en 3 meter høj sten i sort granit på Laurids Skaus grav lige syd for Gammel Haderslev kirke. Hidtil havde en enkel marmorplade smukt og stilfærdigt fortalt, at her var Laurids Skau og hans hustru jordet. Nu var det øjensynligt familien om at gøre at vise, at den afdøde ragede højt op over alle de andre, der var jordet på denne kirkegård. „Godt Navn døer aldrig«, "Efterslægten reiste denne Steen «, står der at læse på stenen, men hvor velment denne handling end har været, så har den dog kun kunnet virke provokerende på Laurids Skaus kritikere.

Havde Laurids Skau end ubestrideligt været stor i dyder, så fand- 


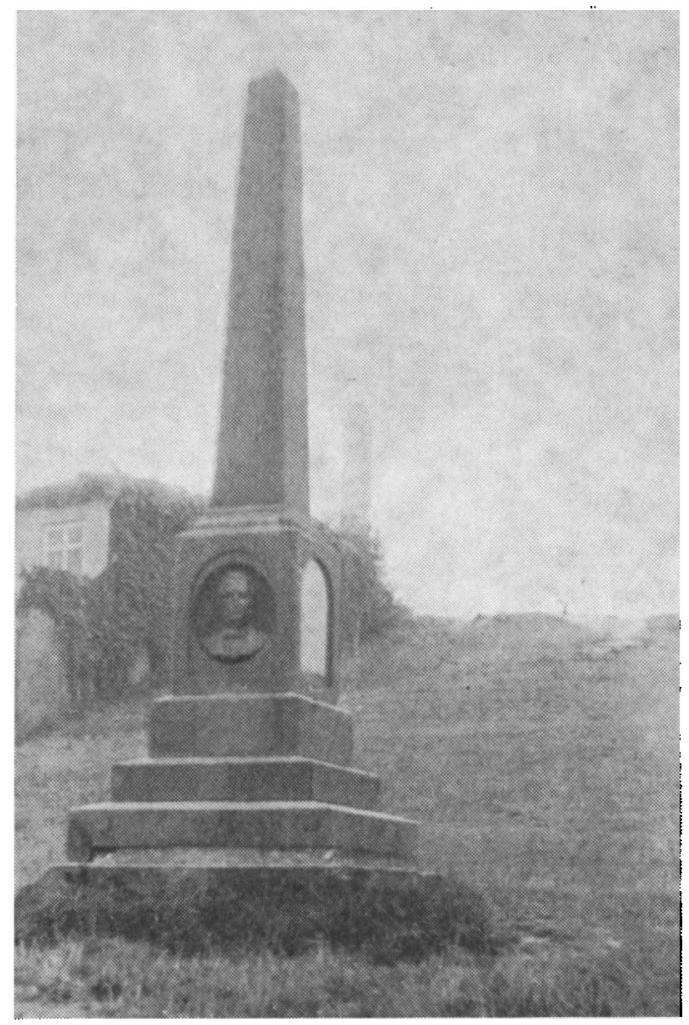

„Den lille Skamlingsbankestotte" har man kaldt mindesmarket for Laurids Skau. I baggrunden skimtes den egentlige Skamlingsbanke-stotte.

(Foto: Carl Gustav

Johannsen, Haderslev, 1969).

tes der dog også adskillige, som mest hxftede sig ved hans lyder. Man påstod, at hans karakter ikke havde været ganske pletfri, og glemte vel altimens, at det kunde man også sige om så mange andre. Laurids Skaus forhold til det smukke køn var vel det, man især vidste at fortælle historier om. Man vidste således at fortælle, hvorledes den galante Laurids Skau, når han fulgte en smuk dame til døren, kunde finde på at holde sin hat frem med ejermandens navn $i$. *Kan De lase, hvad der står her?* kunde han da efter sigende spørge, og uden at afvente svaret læste han med betoning af første led: *L. Skau! «"a

Blandt de mere seriøse anker, som man mente at kunne fremkomme med, var hans skifte fra bonde til embedsmand. Det var dengang noget helt enestående og usædvanligt og måtte derfor næsten 
Laurids Skau

på Gl. Haderslev kirkegård.

Nedenunder ses den

lille marmorplade, der hidtil

havde pyntet graven.

I baggrunden

Gl. Haderslev kirke.

(Foto: Carl Gustav

Johannsen, Haderslev, 1969).

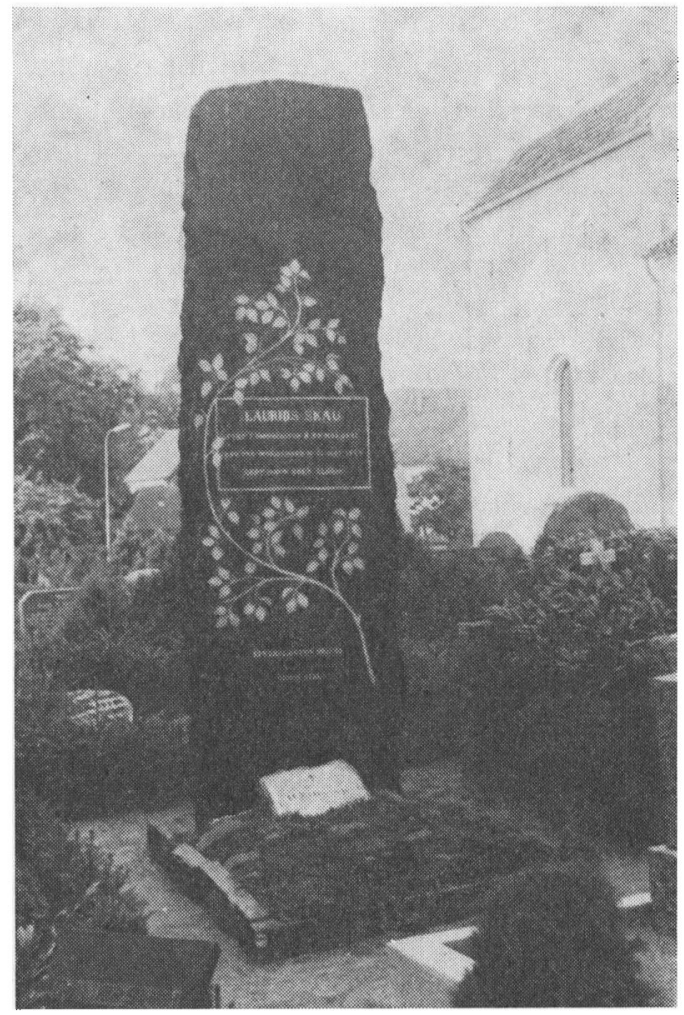

naturnødvendigt føre til misundelse hos mange af hans samtidige. Ikke mindst folk ude vester fra har opfattet ham som én, der var lidt lovlig stor på det. I forvejen kunde det for disse være hårdt nok, at han var flyttet fra Sommersted til det frodige Haderslev østeramt, hvor han var blevet en af denne egns store gårdmænd.

Nøjagtigt det samme var jo tilfældet med Peder Skau til Bukshave i Fjelstrup sogn, og der er næppe tvivl om, at hans kritikere har ment at kunne genfinde adskillige træk fra det apokryfe Laurids Skau-billede, der med årene var skabt ved siden af det officielle. Offentligt til orde kom den slags anker imidlertid ikke. Det forbød simpelthen den danske bevægelses halvt illegale situation. Men tidens breve vidner klart om de brydninger, der foregik.

Og alligevel blev tavsheden brudt af en mand udefra. Det skete 
i 1897 med udsendelsen af pastor Ludvig Hertels bog om hans far, Hans Wilhelm Hertel, der igennem mange år havde været præst ved tre landsbykirker umiddelbart øst og nord for Haderslev, først (1833-41) i Åstrup, senere (1841-48, 1850-67) i Moltrup og Bjerning. Ludvig Hertel, i mange år prxst i Brenderup på Nordfyn, har naturligvis ved at skrive denne bog handlet ud fra de smukkeste motiver såsom sønlig kærlighed og hengivenhed, men det har nok samtidig ligget ham på sinde at rejse faderen et varigt æresminde, og dette har han vel følt så meget mere påkrævet, som Hans Wilhelm Hertels navn ikke findes indhugget på Skamlingsbankestøtten, hvor ellers de store navne fra tiden, »da Sønderjylland vaagnede«, har fundet deres plads til evig amindelse og ihukommelse.

Skamlingsbanke-støtten var blevet rejst, mens Laurids Skau var formand for Skamlingsbanke-selskabet, og det er da kun naturligt, at man i familien Hertel har troet, at Laurids Skau stod bag ved den formentlige uret, der var blevet begået imod Hans Wilhelm Hertel. Den opfattelse har så meget lettere kunnet fæstne sig, som hverken Ludvig Hertel eller andre dengang havde adgang til det valdige brevstof fra disse år, der nutildags findes tilgxngeligt for forskningen. Forholdet var simpelthen det, at man som rettesnor for, hvilke navne der skulde med på støtten, havde stillet som betingelse, at de pågxldende - med Christian Flor som eneste undtagelse skulde være fødte sønderjyder, og Hans Wilhelm Hertel var kommet til verden i Rønnebxk på Sydsjælland. At gøre Laurids Skau ansvarlig, endsige ene ansvarlig for denne vedtagelse, var derfor et skud i blinde. Det viser sig ovenikøbet, at Skau havde været villig til at tage Hertels navn med. Først havde man haft valget mellem $\mathrm{H}$. J. Staal og H. W. Hertel og fundet det naturligt at foreslå Staal, hvis navn var så nøje knyttet til Skamlingsbankens historie, men - fortsætter Laurids Skau i et brev til Orla Lehmann - mhvis Monumentcomiteen derimod maatte ønske eet Navn endnu, vil det være os en Glæde - paa nærmere Opfordring - at foreslaae Pastor Hertel «." Laurids Skau kan vel derfor anses for at have været sagesløs, hvad denne mistanke angår.

Der havde tværtimod hersket det bedste forhold mellem den gamle Hertel og den unge Skau. Skau havde jærnligt sin gang i Moltrup præstegård, og i 1847 havde han datteren Mine Hertel med på en af sine mange rejser til København. Skau rejste da med 


\section{Hans Wilhelm Hertel.}

Bidrag til

den sanderjydsto Polkorakrelses Historte.

Af

L udvig Hertel.

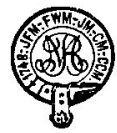

Odense.

Milo'ske Boghandels Forlag.

Milo'ake Bogtrykkeri. 1897.

Titelblad til Hans Wilhelm Hertel:

Bidrag til den sonderjydske Folkevakkelses Historie.

Hos Milo $i$ Odense blev der på den tid trykt mange folkeligt-historiske og religiøse bøger med grundtvigsk præg.

egen befordring. $\gg$ Det turde jo være farligt nu, da jeg har overgivet til Din Varetægt det Kjereste, jeg eier. Af Dit eget og Mines Breve seer jeg, hvor godt og hvor troligt du sørger for hende og fører hende til al den Glæde, som maa være det unge Hjerte kjert «, skriver H. W. Hertel ${ }^{6}$ ved den lejlighed, og i krigens år, da Skau og Hertel levede som flygtninge på hver sit sted, beder Laurids Skau Hertel hilse Mine og tilføjer: "Jeg vilde ønske, jeg en luun Aften kunde stikke mit velbekjendte Gesicht ind ad Din Stue. Skulde jeg i min Glæde falde Eder Alle om Halsen og hændelsesviis endog tilliste mig et Kys i Hidsigheden, saa havde jeg da strax en Leilighed til at bede 


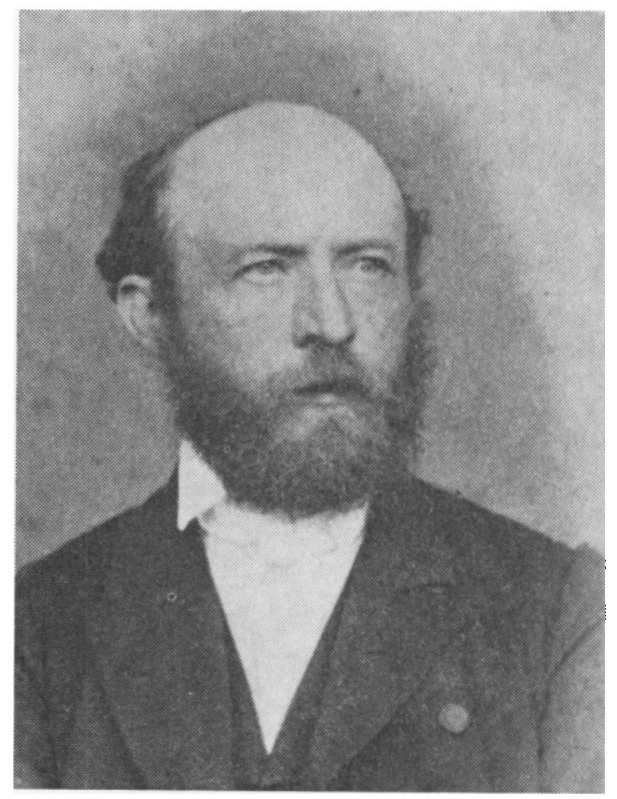

Ludvig Hertel, 1844-1909, horte til de elever fra Haderslev Latinskole, der som folge af krigen $i$ i 1864 forlod skolen med et vidnes. byrd om modenhed og egnethed for et universitetsstudium. Som ung teologisk kandidat var han en kort tid leerer $i$ Kolding, men fik efter at have vaeret prast forskellige steder sin langste tid som sogneprost $i$

Brenderup på Fyn fra 1888 til 1909.

om Forladelse, samt tillige til at see en af de unge Damer rødme langt ned i Halsen «.

Et brev fra et årstid senere tyder ligeledes på det nære venskab, der rådede mellem bonde og præst. Skau skriver her: "Heida Du! Her er jeg! Men hvorfor Satan har Du ikke en eneste Gang skreven mig til? Du vidste dog godt, hvor jeg var, medens jeg ikke kunde vide, hvor en saadan omflakkende Prædikemand som $\mathrm{Du}$ stak $\mathrm{i}$ Verden . $^{7}$

Breve af den art har Ludvig Hertel kendt fra familiens gemmer, og der er den forskel mellem ham og hans brødre og så deres gamle far, at sønnerne havde oplevet den grundtvigske vækkelse. For dem har breve af den anførte slags været til forargelse og har kun kunnet fremme en vis misstemning ved mindet om Laurids Skau. Det samme gælder de breve, der i Laurids Skaus sidste leveår blev vekslet mellem ham og en anden af gamle Hertels sønner, Reinhold Hertel. Den unge mand havde søgt at retfærdiggøre de nye tilstande på Rødding Højskole, som i løbet af Sofus Høgsbros tid som forstander var blevet en udpræget grundtvigsk skole, men Skau lod sig ikke belære 
og skrev i sit svar, at "man ikke slipper igennem Livet med at synge selv de meest nationale Viser. Det nytter ikke, at man uddanner Ungdommen til Føleri for gamle Danmark. Man maae ved Siden deraf gjøre de Unge til praktisk nyttige Borgere. ... Jeg veed meget vel, kjære Hertel! at De selv er Grundtvigianer, men jeg har derfor ikke villet tilbageholde min deelviis strenge Dom om disse, fordi jeg hader Hovmod og Intolerance som Pesten, og fordi det ikke kan skade Dem at kjende netop den Kræftskade, der vil opæde Partiet med alle dets gode Sider, saasnart den gamle Pave er død. ... Forhaabentlig vil De see af det Hele, at jeg vistnok ikke godt forsoner mig med den Art Mennesker, som stille sig op paa Gader og Stræder og udraabe: "Jeg takker Dig, Gud, at jeg ikke er som andre Mennesker eller som denne Tolder « o. s. v., men at jeg paa den anden Side gjerne gaaer 2 Skridt, naar Grundtvigianerne gaae eet, naar dette kan føre til det store Maal: "Folkets Oplysning og Forædling ««. Laurids Skau viser sig her tydeligt nok som oplysningstidens rationalist, mens hans modpart, den unge Hertel, tilhørte det nye slæegtled, der ikke blot havde oplevet den nationale, men også den kristelige vækkelse. Der er derfor efter dette ingen tvivl om, at afstanden mellem Laurids Skau og Hertels børn med årene var vokset, og at det ikke just var et strålende minde, Skau havde efterladt sig hos disse. Det er vel alt dette, som det er nødvendigt at have for øje, når man vil bedømme baggrunden for fremkomsten af Ludvig Hertels bog "Hans Wilhelm Hertel « 1897.

Det er synd at sige, at denne bog forblev upåagtet. Tværtimod! Og det sørgede ikke mindst bogens egen forfatter for! I "Højskolebladet « offentliggjorde han nemlig i november-december $1897^{\circ}$ en art mindeartikel om rigsarkivar A. D. Jørgensen, der netop var død i det selvsamme efterår (den 5. oktober 1897). "A. D. Jørgensen, hans første Fremtræden og sidste Udtalelser «, hedder den, og Ludvig Hertel benyttede den her givne lejlighed til at offentliggøre en række breve, som han havde modtaget fra A. D. Jørgensen i forbindelse med udarbejdelsen af bogen om faderen. Rigsarkivaren havde i månederne før sin død vist Hertel den godhed at gennemlæse hans manuskript, og det var vel ikke mindst for at henlede opmærksomheden på dette, at han skrev artiklen om sin tilknytning til A. D. Jørgensen. Bogen om faderen Hans Wilhelm Hertel havde dermed ligesom fået »det blå stempel «, og det var derfor kun natur- 
ligt, at Ludvig Hertel tilegnede sin bog til A. D. Jørgensen, »Sønderjydernes Historieskriver«. Ligesom rigsarkivaren havde taget forskellige historiske personers virke op til revision (Christian VIII f. eks.), således havde Hertel nu selv $\mathrm{i}$ al beskedenhed ydet et bidrag til en ny vurdering af de personer, der skabte den nationale bevægelse i Sønderjylland, og hans bog har derfor som undertitel: »Bidrag til den sønderjydske Folkevækkelses Historie".

Efter denne forfatterens forhåndsomtale af sin egen bog, gik der nu nogle måneder, før indholdet af Hertels bog kom til almindelig kundskab. Det skete $\mathrm{i}$ form af en anmeldelse i "Højskolebladet ${ }^{10}$, det organ, der på den tid på det nøjeste fulgte den folkelige og nationale litteratur, der kom på markedet, og her hedder det: „Det er ikke saaledes, at Forfatteren idealiserer sine Personer. Nei tværtimod. Han fremhæver alle deres Fejl og det til Tider endog noget stærkt «. "Men det regner jeg ubetinget som et Gode«, føjer anmelderen $\mathrm{F} . \mathrm{Br}$ [uun] til.

Det mente Peder Skau imidlertid langtfra, og han mente tilmed, at sandheden var blevet stærkt fordrejet. Det fremgår meget tydeligt af de randnoter og bemærkninger, som findes $i$ hans eget eksemplar af Ludvig Hertels bog. Ingen kan ved synet af disse notater være $\mathrm{i}$ tvivl om, at han er blevet rigtig godt gal $i$ hovedet under lxsningen af denne bog.

Ikke mindst kommer Peder Skaus harme frem, når Ludvig Hertel finder anledning til at hævde, at Laurids Skau havde mistet bøndernes tillid, f. eks. s. 137, hvor der er tilføjet: "Har aldrig været Tilfældet og behøvedes heller ikke«, og s. 144, hvor der i marginen ud for "voksende Mistillid til Skau « står tilføjet: "atter L. Hertels Løgn «; ligeledes s. 160 nederst, hvor det hedder, at L. Skau ikke var med, »et Udslag af Bøndernes Mistillid«: »Nej, det var Aftale, at Agitatorerne den Gang skulde være udenfor «. Noget bittersødt hedder det nedenunder den skildring, som Pauline Kirstine Seidelin, senere apoteker Aggersborgs hustru i Haderslev, har givet i samme bog, s. 132-137: "Den jydske Pige skulde for sin egen Skyld hellere have ladet dette Æventyr fare! « Ord som "Løgn«, "Sladder «, "fordrejet«, samt spørgsmålstegn og udråbstegn kompletterer det indtryk, som Peder Skau har fået ved lxsningen af Ludvig Hertels bog. ${ }^{11}$ 


\section{Sonderjydske Aarboger}

\section{9.}

Forste Bind.

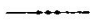

Udgirne

at

H. P. Hanssen-Norremolle, Gustav Johannsen og P. Skau.

Flensbor.

I Hovedkommission hos Gyldendalske Boghandel, Kjobenharn, for Danmark, Norge og Sverrig.

Trykt hos C. K. Thill erup, Flensborg.

Titelbladet til Sønderjydske Aarbøgers forste årgang. Til og med årgang 1913 figurerer $P$. Skau som en af udgiverne. Om baggrunden for årbøgerne kan der loeses $i$ Sønderjyske Arbøger 1964.

Hvad der imidlertid måtte synes endnu værre for ham, var, at Ludvig Hertel nok så frejdigt havde skudt sig ind under A. D. Jørgensens autoritet som »Sønderjydernes Historieskriver «. Dette kunde kun øge Peder Skaus vrede og give ham den opfattelse, at han stod over for en art konspiration, der havde til formål at sværte hans afdøde broders minde. Han havde allerede $\mathrm{i}$ forvejen, ligesom flere andre af sine samtidige, følt ubehag ved A. D. Jørgensens nu så anerkendte arbejde for at rehabilitere Christian VIII. Skønt Peder Skau selv stod opført som redaktør på titelbladet af »Sønderjydske Aarbøger «, var det netop her, A. D. Jørgensens første bidrag til en ny forståelse af Christian VIII og hans tid var udkommet, nemlig 
artiklen "Kristian VIII og Nordslesvig« i 1894 og 1895. At det ikke var sket helt uden indsigelse fra Peder Skaus side, ses af et par linjer fra A. D. Jørgensen til H. P. Hanssen, ${ }^{12}$ skrevet 1895 31/5: "Morten Eskesen mente, at Peter Skau vilde skrive mod mig $\mathrm{i}$ årbøgerne. Lad ham i det mindste vente, til jeg er færdig med aktstykkerne. Har han så lyst til at få sin broder set efter i sømmene, skal jeg gerne tjene ham deri, men det vil næppe blive til glæde«.

Så vidt kom det nu ikke, men det lille intermezzo vidner om, at der havde hersket kold luft mellem A. D. Jørgensen og Peder Skau. $\mathrm{Nu}$ efter fremkomsten af Ludvig Hertels bog og af hans mindeartikel om A. D. Jørgensen kunde denne misstemning kun vokse, og i sin harme og vel også i sin kvide henvendte Skau sig da til sin politiske fortrolige gennem mange år, stiftsskriver $\mathrm{H}$. R. Hiort-Lorenzen $\mathrm{i}$ Roskilde, og denne sendte ham 1897 30/12 følgende svar: "Hertels Bog om hans Fader har jeg ikke seet. ... At Hertel vilde skrive en daarlig Bog, var jeg paa Forhaand overbevist om. En god Bog kan det forvirrede Menneske ikke skrive!«

Også fra anden side er der blevet talt nedsættende om Ludvig Hertels personlige kvalifikationer og det vel at mærke ganske uden forbindelse med den her omtalte sag. Det er pastor Mørk Hansen i Vonsild, der i sine $"$ Livs-Erindringer ${ }^{13}$ omtaler, at den unge Ludvig Hertel gjorde kur til en af datterens lærerinder, "men hun fandt med Føje, at der $\mathrm{i}$ hans Væen var noget latterligt, og at han havde alt for store Tanker om sig selv«. Nu er det nok tænkeligt, at Mørk Hansens bedømmelse kan være påvirket af, at han vidste, at Hertel var grundtvigianer. For en gammel højkirkepræst af mynsterskmartensensk støbning var det noget nær det værste, man kunde blive. Som grundtvigsk præst nåede Ludvig Hertel med tiden et vist ry, ikke mindst på grund af sit virke for Santalmissionen. ${ }^{14}$ Bogen om faderen gav ham derimod ikke det attråede historikernavn. Den skulde tværtimod gøre ham til genstand for megen strid og føre ham ind $i$ en alvorlig og noget pinlig polemik, og den slags fristede ikke til gentagelse.

Den første, der offentligt opponerede imod den nye bog, var lærer J. A. Kloster, ${ }^{15}$ en søn af Laurids Skaus gamle lærer i Sommersted og selv fra sin ungdom af en nær ven af familien Skau. Kloster påtalte meget kraftigt, at det "mange Steder i Bogen uden Føje gaar ud over Laurids Skau. Med den ene Haand klapper Forfatteren, med den 
anden napper han. Mange af Nappene er saarende for L. Skaus Eftermæle. Blandt det groveste er, at Forf[atteren] gør Faderen til Bøndernes Fører, medens L. Skau var det, ja gaar endog saa vidt, at han paastaar, at Bønderne havde forladt denne

Klosters arbejde blev hurtigt opfattet som bestilt arbejde, og det var det også, men snart efter rykkede også selveste Peder Skau frem med en harmdirrende indsigelse, ${ }^{16}$ og dermed var en hel polemik $i$ gang, idet Ludvig Hertel nu måtte ud af busken og give et svar, ${ }^{17}$ hvilket førte til, at Peder Skau nok engang greb pennen for at fremsætte nogle "Afsluttende Bemærkninger $"{ }^{18}$ som det hedder $\mathrm{i}$ slige affærer. Det, Peder Skau særligt slog på, var Hertels alt i alt nedsættende vurdering af Laurids Skaus virke. "Med en Udførlighed og Gaaen i Enkeltheder, der maaske var en bedre Sag værdig, søger Ludvig Hertel at nedsæette Laurids Skaus Betydning. ... At en ung Mand som Laurids Skau ikke kunde blive staaende uanfæxgtet paa den Piedestal, hvorpaa det hele danske Folk i de første Aar af hans offentlige Fremtrxden stillede ham op, er naturligt, og der maatte komme en vis Dalen efter en saadan Rus, men var det ikke mere Lovprisernes end den forgudedes Skyld? « Heri kan man vel kun give Peder Skau medhold.

I forbindelse med den stedfundne polemik modnedes hos Peder Skau planen om at få udarbejdet et historisk værk om Laurids Skau, og det skulde vel at mærke blive et værk, der ud i fremtiden kunde stå som et xrefuldt minde om broderens bedrifter, og som kunde tjene til at lukke munden på hans kritikere. Endnu inden årets udgang havde han haft lejlighed til at drøfte sagen med H. P. Hanssen, der viste sig forstående over for hans problem. Det samme var tilfxldet med $H$. R. Hiort-Lorenzen, der i sit brev af $189730 / 12$ anbefalede ham at henvende sig til Johan Ottosen, Gustav Johannsens svigersøn. Det hedder her: $\bowtie$ Den, der i Øieblikket kunde gjøre det Stykke Arbeide bedst af de Yngre, er Johan Ottosen. Hvad han skrev om min Fader, var godt, og jeg skulde tro, at han maatte kunne skrive lige saa godt om Laurids Skau «.

I sin nytårshilsen til sønnen, Jens Pedersen Skau, afsendt 1898 1/1, så Peder Skau sig derfor $\mathrm{i}$ stand til at aflægge følgende beretning om situationen: »H. P. Hanssens Udsagn er jeg glad ved, thi han har Indflydelse paa Grundtvigianerne. Vil "Højskolebladet « ikke tage den omtalte lille Meddelelse, lad dem saa lade være. Vi skal nok faa 


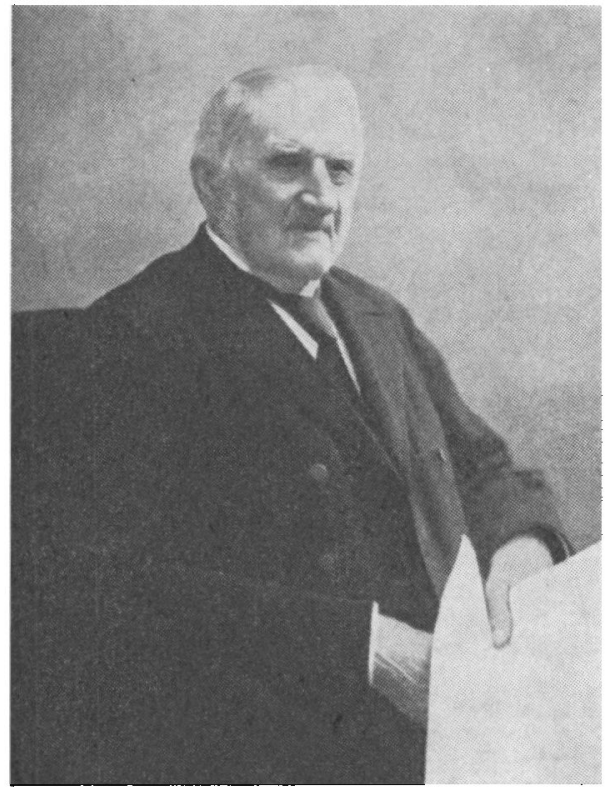

Peder Skau, 1825-1917, en af Haderslevegnens forende politiske skikkelser, ejer af gården Bukshave i Fjelstrup sogn.

Ram baade paa A. D. J[ørgensen] og Pjalten, den ondskabsfulde Ludvig Hertel. Hjort-Lorentzens Henvisning til Johan Ottosen er jo god nok, men det kommer jo an paa, om han har Tid, thi det vil blive et anderledes gigantisk Arbejde, idet Materialet strækker sig fra hans 20. Aar, og da Laurids Skau korresponderede med det halve Danmark $i$ al den Tid og $i$ meget forskjellige Retninger, med den danske Sag som Hovedsag “.

Men snart indløb der til Peder Skau en række svar på de beklagelser, han åbenbart havde givet udtryk for $\mathrm{i}$ anledning af udsendelsen af Ludvig Hertels bog. Redaktør Jens Jessen, »Flensborg Avis«, skrev således 1898 3/1 bl. a. følgende: "Lavrids Skau bliver den, han er, alligevel. Jeg forstår godt, det kan være ærgerligt for Dem, så længe det står på, men af den grund at søge at få udgivet et modskrift mod Hertel synes mig ubetimeligt. Ellers vilde der for øjeblikket næppe være nogen mere passende mand dertil end pastor Richard Petersen, der har skrevet om Kingo, Steffens og flere andre mænd.

Derimod vilde der ikke kunne indvendes noget imod, at De udgav breve til og fra Lavrids Skau. De vilde tale for sig selv. Dette vilde 
uden tvivl være både det værdigste og det, der gør bedst virkning«.

Så vidt Jens Jessen. Det var kloge ord, thi kun en brevudgave er i stand til uden tilsxtning af nogen art at give billedet af manden $i$ hans virke og under de kår, som nu engang var blevet ham til del.

H. P. Hanssen var det højst ukært, at A. D. Jørgensens navn var blevet inddraget $\mathrm{i}$ denne noget pinlige polemik. Alle kendte det nøje venskab, der havde bestået mellem ham og den så pludseligt afdøde rigsarkivar. Det kunde måske endda føre til, at Peder Skaus uvilje mod Ludvig Hertel og A. D. Jørgensen kunde blive overført på ham selv. Han fandt det derfor nødvendigt at oplyse Peder Skau om, hvorledes A. D. Jørgensens stilling til sagen efter hans opfattelse måtte have været. Om han har nået sin hensigt, ved vi ikke, men der er ingen tvivl om, at Peder Skau er blevet glad over at erfare H. P. Hanssens holdning til denne sag. I flere af de politiske situationer, der efter den tid dukkede op på vort hjemlige firmament, var Peder Skau at finde blandt dem, der stottede $H$. P. Hanssen.

I sit brev, dateret 1898 3/4, skriver H. P. Hanssen følgende: "Pastor Hertel har efter min Mening ikke blot gjort sig skyldig i grove Taktløsheder i sin Bog, men ogsaa $\mathrm{i}$ en historisk saavel som politisk set uforsonlig Fremstilling. Flere Afsnit $i$ hans Bog og ligesaa hans Offentliggjørelse af A. D. Jørgensens under hans Sygdom hurtigt henkastede Breve har vakt almindelig Misbilligelse $\mathrm{i}$ vide Kredse. Jeg har personlig især ærgret mig over, at A. D. Jørgensens Navn nu efter hans Død skulde misbruges paa denne Maade og ved et falskt Skin støtte en ensidig Opfattelse, som han ikke delte. Jeg har saa of te haft Lejlighed til at tale indgaaende med A. D. Jørgensen om Lavrids Skau og ved derfor af egen Erfaring, at han, om han end kunde lade skarpe kritiske Ytringer falde om ham ligesaa fuldt som om saa mange andre historiske Personer, der har været Gjenstand for hans kritiske Studium, dog vurderede hans Ævvner saa vel som hans Arbejde og hele historiske Betydning overordentlig højt. Det er derfor ogsaa for mig hævet over enhver Tvivl, at han vilde have nedlagt en bestemt Protest imod den Misbrug, Hertel har gjort sig skyldig $i$, ved at fremdrage fortrolige under en bestemt Sindsstemning fødte Ytringer paa en Maade, der maa give dem en ganske anden Betydning end den tilsigtede«.

Også fra J. N. H. Skrumsager indløb der et brev, men baggrunden for dette var af en noget mere pinlig og personlig art. Det var nem- 
lig kommet Peder Skau for øre, at man på Bejstrupgård i Københoved var fremkommet med nogle ytringer om Laurids Skaus glæde ved et godt bæger. Skaus broderdatter, Marie Skau Petersen på slægtsgården i Sommersted, havde refereret disse udsagn på Bukshave, og den slags har naturligvis ikke kunnet stemme Peder Skau mildere. Skrumsager måtte derfor 1898 11/2 rykke ud med efterstående nærmere forklaring:

"Med hensyn til Din broder og Maries udtalelser af min opfattelse af ham, da må hun have forstået mig forkert. Jeg har aldrig kaldt ham for fordrukken, men sagt, at det var, hvad hans samtidige sagde om ham, at han ofte tog sig et glas mere, end godt var. Og på de to udtalelser er der jo betydelig forskjel. Jeg beklager meget, at jeg ikke fik kjende ham personlig, som jeg ellers har så stor ærbødighed for. Hvad jeg imidlertid ved, var jo det, at han som et skud ud af bondext var noget af det betydeligste $\mathrm{i}$ hans tid og på den plads, han var sat til at virke, men samtidig tror jeg også nok, at han var barn af sin tid og sagde sjælden nej til et godt glas $i$ et behageligt selskab, og da hans stilling førte det med sig, at han tiere end nogen anden af hans samtidige kom $i$ godt selskab, så fik han derved flere glas, end han egentlig havde godt af. Men det er ikke at vare fordrukken! Jeg har jo nu kjendt både Dig og Din broder Eskild i omtrent tredive år. I har jo nok kunnet have Eders glas med $i$ et godt selskab, men jeg har endnu aldrig set, at I ikke kunne holde op i tide eller havt følelse af, I drak med lyst, men kuns for at være tilstede, hvor både alvor og gammen sad hyggelig sammen. Når jeg derfor skal drage en nogenlunde logisk slutning, som jeg gjerne vil skulde passe også på Eders store broder, da er det den, at han i forhold til det muntre lag og gode selskab teede sig som en af Eder, men kom for ofte med ifølge hans betydning og hele stilling «.

Altimens havde Peder Skau modtaget et delvist afslag fra Johan Ottosen på den opfordring til at skrive en bog om Laurids Skau, som han havde sendt efter forslag fra $\mathrm{H}$. R. Hiort-Lorenzen. Dette meddelte han denne $189817 / 2$ i et brev med følgende ordlyd:

„Kjære Etatsraad! Idet jeg oversender Johan Ottosens Brev, beder jeg Dem give mig et Raad, om jeg skal henvende mig til en anden eller, hvad jeg har mest Lyst til, vente, ind til han kan faa Tid der til, saa meget mere, som jeg hos Justitsraad Bruun i Det kongl. Bibliotek saa [Laurids Skaus i 1885 afdøde søn] P. L. Skaus egen 
Haand for, at hans Faders Papirer ikke maatte benyttes før Aar 1900. Dermed er vel ikke sagt, at der nok kan skaffes Adgang til dem, naar der ikke udkommer noget offentlig.

Alle, som jeg talte med, da jeg sidst var i Kjøbenhavn, anbefalede lige som De selv, at Ottosen var den, der bedst kunde gjøre det. Jeg forudsætter ogsaa, at han har venligt Sindelag lige over for min Broders Minde. Jeg vilde f. Ex. aldrig have havt A. D. Jørgensen til at røre min Broders Papirer, thi han vilde da yderligere have benyttet samme som Loftestang for Chr. VIII, hvor det med Rette eller Urette kunde ladt sig gjøre.

Der kommer hver Dag Breve, som Laurids har skrevet til forskjellige. Min Opfordring [om at indsende breve fra Laurids Skau] har altsaa frugtet. Men naar det vil tage saa lang Tid, inden de benyttes, er det vist bedst, at jeg afskriver dem lige saa frit, som de ankommer, og sender Originalerne Retour.

Heldigvis har jeg hans Breve til Sønnerne, som er fortrinlige og kaster et smukt Skjær paa ham, særlig dem til Peter, ${ }^{10}$ da han var $i$ Kjøbenhavns Politiret, idet de er saa uforbeholdne og dog indeholder betydelige Meddelelser om hans Gjøren og Laden til forskjellige Tider herovre, samt om Personligheder.

Jeg har lejet et Aflukke til de vigtigste af hans Breve og Papirer i Hvælvingen i Had[erslev] Bank, hvortil jeg har Nøglen. Jeg turde ikke andet, da jeg jo boer under Straatag.

Vil De nu være saa venlig og meddele mig Deres Mening og saa sende hoslagte Brev tilbage, da jeg saa skriver til Johan Ottosen.

Med venligst Hilsen til Deres Frue og Søster og Deres Børn tegner sig

Deres forbundne P. Skau «.

Efter dette brev hører man ikke mere Johan Ottosen nævnt som forfatteremne til en bog om Laurids Skau. Han var netop i disse år optaget af at skrive sit livs hovedværk, den fortrinlige »Vor Historie « $\mathrm{i}$ tre bind, der vel må anses for at være det mest vellykkede forsøg på en almentilgængelig fremstilling af de nordiske folks historie. Alt dette har selvsagt lagt så meget beslag på hans kræfter, at han har måttet sige definitivt nej til opfordringen om at skrive en Laurids Skau-biografi. Efter den stedfundne polemik har det vel næppe heller været en opgave, der har kunnet friste. 
Jens Jessens forslag om at gøre Richard Petersen interesseret i opgaven synes ikke at være blevet nærmere drøftet. Som en slags stedsøn af rektor Thrige i Haderslev havde Richard Petersen ganske vist tilbragt en del af sin drengetid og tidligste ungdom $i$ Sønderjylland, men det, der særlig fangede hans forfatterinteresse, var tiden omkring 1800-tallet og især personer med tilknytning til både dansk og tysk åndsliv. Madame de Staël Holstein, Jens Baggesen og Sofie von Haller, samt Johan Kaspar Lavater hed nogle af de skønånder, som han $\mathrm{i}$ disse år syslede med, men de lå unxgtelig en kampens og stridens mand som Laurids Skau uendelig fjernt.

Mærkeligt nok synes Peter Lauridsen fra Jegerup ved Vojens ikke straks at være kommet i søgelyset som den forfatter, der burde skrive den attråede Laurids Skau-biografi. Han havde ellers ved siden af sin gerning som kommunelærer, senere skoleinspektør ved det københavnske skolevæsen gjort sig kendt som en ganske habil historisk skribent. Peder Skau har givetvis kendt noget til ham, men han har vel ment at burde holde sig på afstand af ham. Det kan skyldes, at P. Lauridsen som en af de første havde kritiseret den sprogpolitik, som man $\mathrm{i}$ àrene mellem de to slesvigske krige havde fort $\mathrm{i}$ sognene syd for linjen Flensborg-Tønder, ${ }^{20}$ men snarere skyldtes det vel, at han har anset ham for at være knyttet til kredsen omkring A. D. Jørgensen. Denne havde Lauridsen rigtignok også hjulpet med redaktionen af "Sønderjydske Aarbøger « $i$ de første år af dette tidsskrifts eksistens, men dette samarbejde måtte ophøre, ifølge A. D. Jørgensen, fordi P. Lauridsens kritik af de indkomne bidrag forekom ham alt for doktrinær og overlegen."

At afstanden mellem A. D. Jørgensen og P. Lauridsen havde vokset sig større med årene, vidner en artikel i "Tilskueren " 1898 om. $P$. Lauridsen fandt her lejlighed til at sigte den afdøde rigsarkivar som den hovedansvarlige blandt dem, der $\mathrm{i}$ disse års sønderjyske litteratur havde påtaget sig at give en ny vurdering af de mænd, som havde haft deres virke $\mathrm{i}$ den nationale vækkelses år. »Levnedsskildrere er meget nyttige«, skriver P. Lauridsen videre, "men ofte også ret ubillige Historieskrivere; de betages let af et biografisk Elskeri, der gør dem blinde for andres Fortjeneste og sommetider fører dem helt ud i det urimelige. Saa stadses Kong Kristian VIII op til en national Politiker af høj Rang, saa trykkes der om Hjort Lorenzens Pande en Laurbærkrans, hvis Blade ikke alle er lige ægte, 
A. D. Jorgensen, 1840-97, „Sonderjydernes Historieskriver", virkede siden 1882 som geheimearkivar (siden 1889 rigsarkivar), initiativtager til Sonderjyske Arbager. Som historiker tog

han til genmale mod den nationalliberale tids historieopfattelse.

og saa rejser Pastor Hertel sin Fader en Bautasten, der vilde have staaet sikrere og mere blank, hvis han havde ladet Flors Hæder uanfægtet «.2

De få linjer lader ane, at P. Lauridsen også havde sin helt, nemlig Christian Flor, men ellers er hans sidehug til A. D. Jørgensen (på grund af Christian VIII), Johan Ottosen (Peter Hiort Lorenzen) og Ludvig Hertel jo åbenbar nok. Han havde eftertrykkeligt dementeret alle påstande om, at han hørte til A. D. Jørgensens kreds, og da han derfor selv henvendte sig til Peder Skau for at bede om tilladelse til at se Laurids Skaus brevarkiv i Det kongelige Bibliotek i Kobenhavn, havde denne intet at indvende herimod, og det så meget mere, som P. Lauridsen i sit brev af $190027 / 9$ forstod at forme sit ønske $i$ efterstående, særdeles velvalgte ord:

"Maaske vil De endnu erindre, at jeg i Foraaret fortalte Dem, at jeg forberedte Udgivelsen af en Fremstilling af Prof. Flors Betydning for Nordslesvig fra 1837 til 1848. Jeg har i dette $\varnothing$ jemed gjort en Del Studier og samlet et stort Materiale, navnlig Breve til og fra 
Flor, men savner Kendskab til de Breve, som han vekslede med Deres Broder, L. Skau. Jeg har talt med Bibliothekaren ved det st[ore] kgl. Bibliothek (f. T. Hr. Weeke) derom, og han mener, at jeg fra Bibliothekets Side kan faa Adgang til disse Flors Breve iblandt Laurids Skaus efterladte Papirer, hvis den afdødes Familie (altså vel først og fremmest De) ikke havde noget derimod og skriftlig vilde give mig en Bemyndigelse til at se dem. ... Det følger af sig selv, at disse Breve ville blive benyttede med den største Skønsomhed og med Udeladelse af alle Enkeltheder, der ikke have historisk Værd eller kunde være saarende for Familien.

Jeg antager forøvrigt, at min Opfattelse af den Tids Begivenheder og Personer er saa sympathetisk, at De ikke behøver at frygte nogen ensidig eller skæv Dom over Deres Broder, og jeg mener desuden, at Flors Breve til ham, navnlig 1842-44, maa indeholde en Rigdom af Oplysninger baade om Deres Broders store Evner og Betydning for den danske Sag og om Udviklingen i det hele, saa at en fuld Opklaring af Skaus og Flors Samarbejde i disse Aar nu ikke alene er ønskeligt, men endogsaa ret nødvendigt. Som født Nordslesviger bortgiver jeg selvfølgelig ikke en Tøddel af den Ære, der med Rette falder paa vor egen lille Folkedel, og Laurids Skau vil dog alle Dage blive staaende som en af de dygtigste og mærkeligste Skikkelser, Nordslesvig hidtil har fostret.*

Ikke mindst efter at have læst den sidste del af dette brev må det have stået Peder Skau klart, at her var den historiker, han søgte: en mand, fra hvem man ikke behøvede at frygte nnogen ensidig eller skæv dom« over Laurids Skau. At P. Lauridsen allerede på det tidspunkt havde vovet sig frem med nogle alt andet end smigrende vendinger om Laurids Skau, har broderen på Bukshave nok ikke vidst. Han har næppe været læser af »Aarbog for dansk Kulturhistorie «. ${ }^{23}$ Efter nogen overvejelse besluttede Peder Skau sig derfor til at anmode $P$. Lauridsen om at påtage sig den opgave at skrive en bog med Laurids Skau som hovedperson.

P. Lauridsen stilede imidlertid videre. Han drømte om at blive den historiker, der skildrede hele den nationale vækkelsestid fra 1830 til 1864, og her vilde Laurids Skau jo rent naturligt komme til at indtage en fremtrædende plads. Snart måtte han imidlertid indse, at det ikke vilde blive ham muligt at fà kendskab til brevarkiverne 
efter 1850, og 1901 20/11 satte han Peder Skau ind i dette sagforhold ved følgende brev:

»Friskolen i Husumgade, d. 20 de Novbr. 1901.

Kære Hr. P. Skau!

Det har taget mig nogen Tid at blive klar over det ærefulde Hverv, som De har stillet mig, og at gennemgaa Deres afdøde Broders Papirer, saaledes at jeg kunde danne mig en foreløbig Anskuelse om det Arbejde, som deres Bearbejdelse vil kræve. Jeg maa da straks bemærke, at Laurids Skaus Papirer væsentlig kun indeholde Breve, ikke i nogen fremtrædende Grad samlede Afhandlinger, og at disse Breve ikke kunne forstaas uden et meget nøje Studium af Tidshistorien. Fra Slutningen af 1842 og til 1864 er Deres Broders Levned saa afgjort kædet med ind i Nordslesvigs nationale Udvikling, at en Biografi af Laurids Skau nødvendigvis maa forme sig til en Fremstilling af den nævnte Udvikling, hvis Biografien skal have Fylde og Værd.

Dette paavirker $\mathrm{i}$ højeste Grad min Stilling til Sagen. Jeg magter at skrive den nationale Udviklingshistorie fra 1830 til 1848, fordi alle væsentlige Kilder der staa til min frie Raadighed, og et saadant Arbejde, hvori der ogsaa paa det mest indgaaende tages Hensyn til Laurids Skaus Virksomhed, vil forhaabentlig fremkomme fra min Haand i Løbet af et Aars Tid.

Men efter 1848 ere Vanskelighederne meget store. Rigsarkivets Akter efter denne Tid ere ikke tilgængelige, heller ikke har jeg hidtil kunnet faa Adgang til afdøde Etatsraad Regenburgs Papirer (o. en Snes Pakker), Regeringens Opfattelse og Fremgangsmaade kan derfor kun højst overfladisk belyses, og jeg har - som naturligt er ikke i den korte Tid kunnet forskaffe mig et Skøn over, hvorvidt Deres Broders Brevskaber, og hvad der foreligger i den trykte Literatur, vil være tilstrækkeligt til at give et tilforladeligt Tidsbillede.

Intet skulde være mig kærere end, om det maatte forundes mig opvokset i Nordslesvig til mit 20. Aar og gennemtrængt af den særegne Danskhed, som særlig ved Deres Broders og Prof. Flors Hjælp gennemtrængte næsten alle - at skildre vor nationale Kamp fra 1830 til 1864, men jeg kan paa den anden Side ikke lægge Skjul paa, at denne Opgave ikke vil kunne løses blot ved en Biografi af Laurids Skau. Jeg henvender mig derfor til Dem om at faa frie Hænder. Jeg vil gaa $\mathrm{i}$ Lag med en Bearbejdelse af Deres Broders Breve (som jeg 
har gennemarbejdet Flors, Kochs, Prof. Paulsens, Fischers o. fl. a. Samlinger) ikke for at skrive deres Biografi, men for at skildre hele Udviklingen, hvori de greb ind. Det er muligt, det er vel endogsaa sandsynligt, at Deres Broder fra 1853 til 64 fortjener en monografisk Behandling, og det skal da være mig kært at udarbejde en saadan med al den Sympathi, jeg raader over for den frrste "nordslesvigske" Bonde, men noget bestemt Løfte kan jeg ikke afgive i denne Retning.

Endnu skal jeg dog erklære, at jeg vil gaa til dette Arbejde uden egen Ærgerrighed. Jeg hader af min ganske Sjæl den Forfatter[for]fængelighed, der søger at vække Opsigt paa den sande Histories Bekostning. Det er ikke umuligt ved Hjxlp af Deres Broders Breve til Flor fra 1843-45 at vække en forargerlig Opsigt, ja, jeg anser det endogsaa for onskeligt, at disse Breve foreløbigt bliver $i$ Familien (o: mellem os Nordslesvigere), og Bibliothekar Lange har erklæret, at han vil holde alle andre borte fra dem, hvis jeg (eller en anden efter deres [ $=$ Deres] Anvisning) bemyndigedes til at bearbejde dem. Jeg maa derfor bede Dem om at bestemme Dem. Jeg tor ikke love at skrive en Biografi af L. Skau, men jeg har til Hensigt, hvis mine Krxfter slaa til, at give en samlet Fremstilling af den nationale Bevægelse i Nordslesvig fra 1830 til 64, og i denne at tage tilbørligt Hensyn til L. Skau. Hvis De er tilfreds dermed, imødeser jeg et Par Ord fra Dem, og samtidig vilde det glæde mig meget fra Deres Haand at modtage en Karakteristik af Deres Broder som Menneske og Politiker.

Med venlig Hilsen forbliver jeg

Deres hengivne P. Lauridsen.«

Med dette brev var temaet $\mathrm{i}$ virkeligheden anslået for $\mathrm{P}$. Lauridsens store livsværk, "Da Sønderjylland vaagnede«, og værkets tidsmxssige begrænsning til årene fra 1830 til 1848 var ligeledes nu afgjort. En Laurids Skau-biografi måtte familien finde sig i foreløbig at give afkald på, men det har været Peder Skau indlysende, at dette tidsrum af Sønderjyllands historie overhovedet ikke lod sig behandle, uden at man også kom ind på Laurids Skaus livshistorie og gav ham en central placering. Intet var derfor naturligere end at give P. Lauridsen tilladelse til at benytte Laurids Skaus brevarkiv. Nu var man jo også ude over året 1900, som Laurids Skaus søn havde fastsat som skæringsår for arkivets benyttelse. 


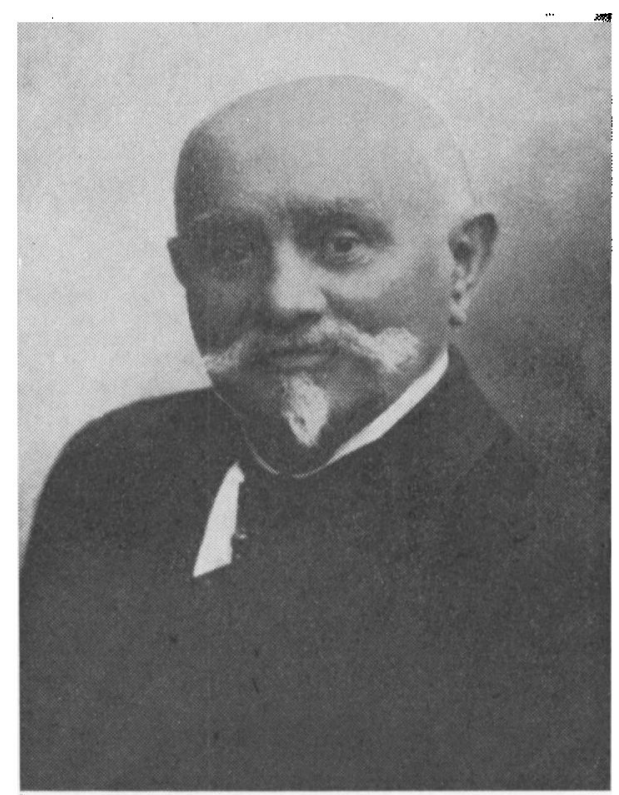

Peter Lauridsen, 1846-1923, hom som ung optant med larereksamen fra Tonder til Kobenhavn, hvor han fandt ansattelse ved skolevosenet, 1892. 1919 som inspektor ved Husumgades skole. - I forbindelse med noget stof, som han $189919 / 9$ sendte Poul Bjerge $i$ Askov, skriver P. Lauridsen: „Jeg har nu givet Dem noget af mit Hjarteblod; bare det ikke er for meget. De fortaller mig saare elskvardigt, at vi shulle have Are af vort Vark, men jeg er aldeles ikke forvant. Jeg frygter snarere, at vi fau Spot og Skoser; vi hore ikke til Laget, vi ere Seminarister og $H_{o j-}$ skolefolk, og Akademikerne tillade maaske endnu ikke, at den Slags Karle have en forbandet nargaaende Mening“. Efter sit store varks far. diggerelse opnåede han ikke des mindre at blive dr. phil. honoris causa ved Kobenhavns Universitet.

Der gik nu flere år, optaget af arbejdet med det store værk. Peder Skau havde altimens sendt $P$. Lauridsen sine erindringer til gennemlæsning, som denne 1907 11/6 foreslog en del rettelser til, især de folgende linjer om forholdet mellem Flor og Laurids Skaus taler:

"Maatte jeg til Slutning gøre en eneste Bemærkning, som Du bedes om at optage $i$ den bedste Mening. Vilde det ikke være rigtigt at indflette en Bemærkning om, at Flor havde været medvirkende ved Affattelsen af Laurids Skaus første Taler? Det kan jo gøres ganske en passant, og Du havde paa Forhaand afvabnet en Kritik, som 
meget let kan kaste sig over dette Punkt efter Hertels og A. D. Jørgensens Oplysninger.«

Her havde P. Lauridsen rørt ved et meget ømtaaleligt problem, og da han mærkede Peder Skaus reaktion, så han sig 1907 11/11 nødsaget til at give en længere udredning af sit syn på forholdet mellem Christian Flor og Laurids Skau:

"Jeg har tænkt meget over Laurids Skaus Forhold til Flor og mener at kende det ud og ind, bedre end nogen nulevende. Det kan selvfølgelig ikke negtes, at Flor talte igennem ham $\mathrm{i}$ hans første Taler, men han - Flor - gjorde dette først og fremmest, fordi han ikke kunde selv, og fordi heller ingen anden end Laurids Skau kunde tale, som der skulde tales. Skau talte paa det nationale Partis Vegne, han gav Udtryk for dets Tanker i store og betydningsfulde Situationer, og han bar sig ikke anderledes ad end mange andre store Talere baade før og efter ham, uden at disse har været Genstand for en smaalig og snusende Kritik bag efter. Dette vilde Skau sikkert heller ikke være bleven, hvis ikke Koch-Flors store Brevsamling paa det $\mathrm{kgl}$. Bibliothek havde opbevaret omtrent enhver Linie, der er vekslet mellem Datidens Førere, ogsaa Skaus Breve til Flor om de omhandlede Taler.

En hel Fortielse af Forholdet er derfor næppe klogt, og jeg synes, at Din Bemærkning en passant er ganske paa sin Plads. Kun vilde jeg maaske nok lægge endnu større Vægt paa Skaus oratoriske Evne, der, hvorledes man end drejer og vender Sagen, dog vedbliver at være en Hovedside. Jeg vilde forme den indklamrede Sætning i Dit Brev omtrent saaledes:

"Det kan saamænd gerne være sandt, men det maa erindres, at L. Skau ved disse Lejligheder befandt sig $i$ en stor og mærkelig Situation. Han skulde tale ikke alene paa egne, ikke alene paa de slesvigsk-nationales, men paa hele Nordslesvigs Vegne, og han skulde desuden tale saaledes, at hans Ord gav Genlyd i hele det danske Folk. Under disse Omstændigheder, synes mig, kan det ikke lægges ham til Last, at han søgte Støtte hos den ældre og modne Fører, og at han derved kom til at tale, som ingen anden dalevende Slesviger kunde have talt . $^{24}$ Desuden er jeg overbevist om, at alle, som hørte ham tale, havde Følelsen af osv., osv., som Du har skrevet det.

Hvorledes man end vil se paa det, maa det dog stadig erindres, at L. Skaus første Taler havde Storladenhedens Præg, var noget af en 
patriotisk Bedrift, og den Ros, forekommer det mig, skal han ogsaa have i sin Broders Erindringer.*

I sit næste brev meddelte Peder Skau, at han agtede at udgive nogle barndoms- og ungdomserindringer, som Laurids Skau havde efterladt sig. Det blev til skriftet $»$ Blade af Laurids Skau's Livshistorie«, der udkom 1908. Denne udgivelse skal vel ses som udtryk for utilfredsheden med, at det trak ud med P. Lauridsens arbejde. Han skyndte sig derfor 1908 4/9 at meddele Peder Skau, at nu var det første bind på trapperne:

"Jeg blev helt overrasket ved Meddelelsen om, at Laurids Skau har efterladt sig Optegnelser indtil 1843. Det vil interessere mig umaadeligt at lese dem, men - for mig $\mathrm{i}$ det mindste - er det ret drillevorent, at de ikke gaar længere. P. C. Koch i Haderslev har baaret sig akkurat ligesaadan ad. Han har begyndt paa en fortrinlig Fortælling om sit Liv, men er ikke naaet længere end til Efteraaret 1838, tre Maaneder efter det første No. af Dannevirke. Hvor interessant, om disse, hver paa sin vis lige ypperlige Nordslesvigere, havde tegnet os et Billede af deres Liv fra 1838 til 64. Nu maa dette Billede arbejdes sammen fra mange Sider, og det er just ikke noget let Arbejde.

Jeg har været saa heldig ved Prof. Edvard Holms Hjælp at faa en Understøttelse paa c. 17-1800 Kroner til Udgivelse af et historisk Vxrk om den nationale Kamp i Nordslesvig fra 1837-1848. Det vil forhaabentlig udkomme i Løbet af Aaret 1908/09 under Titelen: - Da Sonderjylland vaagnede «, Skildringer og Breve. Sandsynligvis vil det svulme op til 4 store Bind og give et meget stort Antal Breve fra Flor, Paulsen, Koch, Fischer, Skau, P. H. Lorenzen, Hertel o. fl. a. Det første Bind er næsten færdig til Trykken, og heri findes ogsaa de første Breve fra Laurids Skau til P. C. Koch og Flor, men det følger af sig selv, at dette Bind - alene paa Grund af Skaus Ungdom - kun i ringe Grad vil beskæftige sig med ham. Senere træder han jo helt frem i Forgrunden."

Omsider udkom da 1 . bind af $" \mathrm{Da}$ Sønderjylland vaagnede« $\mathrm{i}$ 1909, og i 1911 fulgte endda 2. bind, men i begge disse bind nævnes Laurids Skau kun ganske perifert. Det var den nationale historie frem til 1838, og det var Frederik Fischers virke i Âbenrå, der var emnet for de to bind. Peder Skau måtte derfor stadig finde sig $i$ at vente på det bind, der skulde have Laurids Skau til hovedperson. 


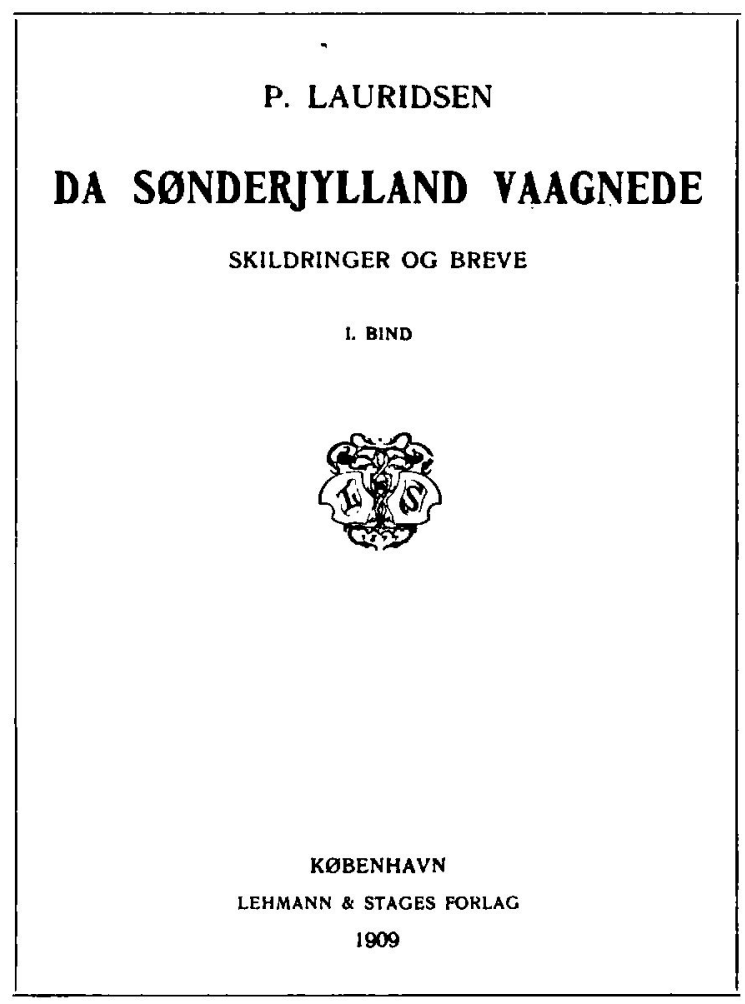

Titelblad til P. Lauridsen:

Da Sonderjylland vaagnede.

Udgivelsen blev med årene overtaget af Haases Forlag.

I 1915 var han blevet 90 år gammel, og man ligesom aner, at P. Lauridsen har haft en ganske bestemt hensigt med at trække tiden ud. Han har haft sine gode grunde til ikke at ønske bindet om Laurids Skau udsendt $\mathrm{i}$ broderens levetid.

I 1916 fulgte ganske vist 3. og 4. bind af den bredt anlagte fremstilling $\mathrm{i}$ forbindelse med udgivelse af tidens brevstof, men nok engang lykkedes det $P$. Lauridsen at komme uden om behandlingen af Laurids Skaus indsats, idet de to bind standser op ved 1842. Efter sigende skal Peder Skau efterhånden være blevet klar over P. Lauridsens grunde til at vente med udsendelsen af sin omtale af Laurids Skaus virke. Ifølge et udsagn af broderdatteren Marie Skau Petersen 
skal han ved lejlighed have sagt: $:^{25}$ "Min brors papirer er ikke $\mathrm{i}$ gode hænder. Lauridsens bog kommer ikke, så længe jeg lever «.

1917 7/3 døde Peder Skau i en alder af 92 år, og straks i 1918 var P. Lauridsen der med sit 5. og 6. bind med den store omtale af Laurids Skau, og det blev til en usædvanlig hård og alt $i$ alt uforstående kritik af Laurids Skau. Nok måtte han indrømme, at "den unge Laurids Skau aldrig vil dø", men ellers hedder det bl. a.:" "Sammenlignet med de andre Førere var hans Væsen uden Lødighed. ... Inderst inde var Skau en lidet positiv Natur - en talentfuld Laaner, Gengiver og Udnytter uden egne Ideer og nyskabende Evne. I Længden formaaede hans smidige Intelligence og Energi ikke at dække over Tomheden «.

At denne negative opfattelse straks er blevet forstået, ser man bl. a. af den anmeldelse, der fremkom i dagbladet "København « ${ }^{27}$

"Mest interessant er maaske Behandlingen af Laurids Skau. Og dog - her er der et Punkt, hvor selv Lauridsens Sandhedstrang ikke har drevet ham til at tale rent ud. Det skal indrømmes, at han har ladet Dokumenterne tale - særlig i sjette Binds Brevsamling. Men han har ligesom undset sig ved fuldkommen at bryde Staven over denne naive, forlorne og sprænghovmodige Teaterhelt, der takket være laante Fjer blev pyntet som et dansk Afgudsbillede og siden benyttede denne Ophøjelse til at tilfredsstille sin Forfængelighed paa den puerileste Maade. Der nævnes næppe et eneste Træk i Bogen, som vækker virkelig Sympati for Laurids Skau. Men Dommen over ham udtales paa en - $i$ Forhold til saa mange andre af Bogens Domme - skaansom Maade. Det kaldes for Fantasteri og forbavsende Mangel paa Hukommelse, hvad næppe kan karakteriseres som andet end bevidst Fordrejelse, bevidst Usandfærdighed.

Vi regner det for et Gode, at denne Demagog saa ubarmhjertigt er afsløret gennem de meddelte Brevskaber. Den slesvigske Folkevækkelse var saa gennemægte, saa sand og dyb, at den med Lethed kan skyde Uægtheden og den personlige Forfængelighed af sig uden at lide derved.«

Denne noget flotte og letkøbte journalistbehandling af Laurids Skaus livsværk fik omgående et svar, thi således mindedes de to brødre fra Vilstrup præstegård, Frede og Peter Bojsen, i hvert fald ikke Laurids Skau fra de unge år. De sendte derfor omgående et indlxg til samme avis med følgende indhold: $:^{28}$

*Vi to Brødre hører vel til de sidste af dem, der har kendt Laurids 
Skau personlig, og vi føler os derfor opfordrede til at gøre Indsigelse imod den altfor skarpe Dom [over Laurids Skau]. Vi har hørt ham i 50erne paa Skamlingsbanken og levet i By sammen med ham i Houst ved Vilstrup. Vort Indtryk er da dette:

Laurids Skau kan i personlig Storhed ikke staa Maal med Broderen Peter Skau og endnu mindre med Hans Krüger, der var den robuste Legemliggørelse af en stor Idé. Laurids Skau havde derimod i Vuggegave en medfødt Veltalenhed, som dengang var langt sjældnere end nutildags. Han besad nxppe nogen stor Originalitet $\mathrm{i}$ Tanken. Meget muligt, at han ofte udskød Kugler, som andre havde støbt. Rygtet sagde jo endog, at Flor havde skrevet den berømte Tale paa Skamlingsbanke i 1844. Men for den, der bliver ramt af Kuglen, vil Skytten have mere Betydning end Kuglestøberen. Den Evne at kunne med Ord levendegøre endogsaa andres Tanker saaledes, at Tilhørerne var overbeviste om, at Talerens eget Hjerte $i$ alt Fald bankede med deri, det er en Evne af umaadelig Vxgt. Man siger: Laante Fjer! Skuespiller! Nu vel. Hele den »dannede Verden«, som hilser og hylder sine store Skuespillere, vil ikke kaste Vrag paa den Kunst, der tager baade Aand og Hjerte med i Fremstillingen.

Ved Siden heraf maa heller ikke glemmes hans høje, smukke Skikkelse og vindende Fremtræden. Dette støttede ogsaa hans ypperlige Evner som Selskabsmand. Han kunde være den fine, endogsaa elegante Mand blandt Embedsmændene og dog den jævne Mand med sønderjydsk Maal i Landkredse.

Sxrligt mindes vi ham som den store Danser ved Brylluppet hos gamle Bramsensgaard, hvor alle de ny danske Embedsmænd var indbudte i Begyndelsen af 50erne. Han var da iført lysegraa Benklæder, og med sine lange Ben tog han hele det store Ladegulv $\mathrm{i}$ et Par Spring af en Kontradans.

Da han blev ansat som Amtsforvalter i Haderslev og siden nærmest fulgte den daværende Regering, svandt hans Betydning som folkelig Fører efterhaanden, medens han stadig viste sig som en dygtig Ordfører for de Danske i Stændersalen.

Om hans personlige Sindelag satte Begivenhederne vistnok et sandt Mindesmærke ved hans Grav: Han døde nogle faa Dage efter Dybbøls Fald.

Dette til Værn for Laurıds Skaus Minde imod bitre Ord.. 
Lad os med disse ord fra et par af dem, der endnu huskede og mindedes Laurids Skau, slutte denne noget lange og omstændelige redegørelse for et ejendommeligt kapitel af vor sønderjyske historieskrivnings historie. For alle parter $\mathrm{i}$ den her behandlede sag blev udgangen tragisk, naturligvis først og fremmest for Peder Skau og hans slxgt. Med megen ret har man her følt bitterhed mod en mand, der så ensidigt havde fremstillet slægtens store mand, og man har indset, at redaktor Jens Jessen havde ret, da han skrev, at kun en brevudgave vilde kunne give et tilforladeligt billede af et så særpræget og nuanceret menneske, som Laurids Skau nu engang var.

Også for P. Lauridsen blev udgangen af sagen forsåvidt tragisk, thi han måtte vente de mange og lange år, inden han kunde få udsendt det store værk, som han med rette anså for sit livsværk, og som hans navn for stedse vil være knyttet til. Forst i 1922 fik han det afsluttet med et 7. og 8. bind. Han var da næsten 76 år gammel. Københavns Universitet mente efter værkets afslutning at burde belønne ham med titlen dr. phil. h. c., men det var lidt vel sent, at man traf denne beslutning, thi han døde kun godt et halvt år efter og tilmed - som det nævnes i nekrologerne - efter lang tids sygdom.

\section{NOTER OG HENVISNINGER}

1. Jakob Petersen: Skamlingsbanken 1843-1943, s. 133.

2. LA. Peder Skaus arkiv. Her findes også de ovrige citerede breve, som er stilet til Peder Skau.

3. Se f. eks. P. A. Madvig til H. R. Hiort-Lorenzen 1875 13/7:

* Hvis Kryger nemlig snart maa holde sig tilbage, er Deres Plads afgjort i Haderslev, hvor Deres Valg uanfægtet vilde gaae igjennem, medens der dog maaske kunde vise sig Vanskeligheder $\mathrm{i}$ Graasteen, og naar P. Skau raader Dem til at søge Valg paa sidste Sted, saa er jeg bange for, at han gjør det med den Eventualitet for Øie, at han snart kunde komme til at forsøge sin Lykke i Haderslev, medens han maa sige sig selv, at han er en Umulighed paa det andet Sted. Skulde det komme dertil, vilde jeg meget beklage det, thi deels anseer jeg ikke Skau for Manden, der skal sendes til Berlin, deels er jeg overbeviist om, at hans Candidatur heri Kredsen vilde vakke en heftig Strid.

En anden Ting, hvorom man ogsaa maa være paa det Rene, inden De seger Valg i Graasteen, er, hvorvidt Ahlmann er gaaet i sine Anbefalinger af Hans Lassen i Lysabild, en Ting, hvorom jeg heller ikke er paa det Rene .

Dette og de øvrige citerede breve til H. R. Hiort-Lorenzen findes i Det Kgl. Bibliotek ( $\mathrm{Ny}$ kgl. samling 1725).

4. Jakob Petersen: Skamlingsbanken 1843-1943, 1943, s. 160-163. 
4a. Det lille trak er fortalt mig af redaktør Morten Kamphövener, Abenrå. Helt glemt var vel heller ikke Laurids Skaus venskab med Julie Marckmann, se: H. V. Gregersen: Præstefamilien Marckmann i Hoptrup (Sønderjysk Månedsskrift 1967, s. 172-191).

5. H. V. Gregersen: Laurids Skaus brevveksling med politiske venner i København, 1966, s. 226 . -

At det netop var det savnede navn på Skamlingsbanke-støtten, der havde vakt anstød, fremgår også af en mindeartikel om Hans Wilhelm Hertel, som presten Ludvig Wagner, en svoger til Ludvig Schroder på Askov, bragte i * Højskolebladet 1900 , sp. 585-594. Det hedder her til sidst: $¥$ Paa Skamlingsstatten er der endnu Plads til 2 Navne. Men det er Uret imod Sønderjyllands Saga og imod Hertels Minde, at ikke den ene af Pladserne bliver udfyldt af Navnet paa ham, hvem hans gamle Kampfalle Flor en Gang ved en Fest kaldte *Den sidste paa Skansen*«. Wagner ved også at fortælle, at Laurids Skau og Hans Krüger engang i sommeren 1863 besøgte den gamle præst i Moltrup præstegård.

6. Det Kgl. Bibliotek (Ny kgl. samling 1727).

7. RA. Hertels arkiv. - Hvad Modtageren har haft for Folelser ved at tiltales paa denne Maade, ved vi ikke «, skriver Carsten Petersen i sin bog Slesvigske Praster, 1938, hvor han har citeret sidstnevnte brev.

8. RA. Hertels arkiv, trykt: Fra Højskolens Ungdomstid, I, s. 69-73.

9. *Højskolebladet 1897 , sp. 1500-1507, 1530-1536, 1559-1570. Et af brevene er genoptrykt: Harald Jørgensen: A. D. Jørgensens Breve, 1939, s. 410.

10. *Højskolebladet $\propto 1897$, sp. 1521-1523.

11. Peder Skaus eksemplar af Ludvig Hertels bog findes i Skau-familiens eje. Hans tilføjelser har jeg overført til mit eget eksemplar af denne bog.

12. Harald Jørgensen: A. D. Jørgensens Breve, 1939, s. 377.

13. M. Mørk Hansen: Livs-Erindringer, 1968, s. 257.

14. Se f.eks. Lorenz Bergmanns artikel om Ludvig Hertel i Dansk Biografisk Leksikon.

15. $*$ Højskolebladet * 1898, sp. 659-662.

16. Højskolebladet $\propto 1898$, sp. 1007-1012.

17. Hejskolebladet 1898, sp. 1135-1139, 1170-1175.

18. Højskolebladet 1898 , sp. 1491-1494.

19. Det er tanken at bringe disse $i$ en planlagt publikation: Laurids Skaus brevveksling med politiske venner i Sonderjylland.

20. P. Lauridsen: Efter 20 Aars Fremmedherredømme (Tilskueren 1884, s. 825845). Den førte til, at M. Mork Hansen skrev afhandlingen: Om Sprogforholdene i de blandede Egne af Sønderjylland ('Tilskueren 1885, s. 226-245).

21. Udtalelse $\mathrm{i}$ brev til $\mathrm{H}$. P. Hanssen, jvf. Harald Jørgensen: A. D. Jørgensens Breve, 1939, s. 268.

22. P. Lauridsen: Det nationale Gennembrud i Sonderjylland (Tilskueren 1898, s. 261-285, 359-379). P. Skau har rimeligvis fået kendskab til denne afhandling, fordi Ludvig Hertel også langer ud efter den i sit svar til P. Skau i *Højskolebladet * 1898, sp. 1135-1140, 1170-1176.

23. P. Lauridsen: Professor C. Flor og Nordslesvigerne (Aarbog for dansk Kulturhistorie, udg. af Poul Bjerge, 1898), anmeldt af Ludvig Hertel $\mathrm{i} *$ Højskolebladet 1899 , sp. 697-702.

24. Peder Skau har ord til andet benyttet P. Lauridsens forslag $i$ sin bog Minder fra mit Liv og min Tid, 1909, s. 12. 
25. Citeret efter en udtalelse af pastor emer. Detlefsen, tidl. Bylderup, nu bosat i Sommersted, i forbindelse med et foredrag om Laurids Skau, der er blevet trykt $\mathrm{i}$ » Sprogforeningens Almanak 1969 , s. 68-83.

26. P. Lauridsen: Da Sønderjylland vaagnede, V, 1918, s. 59, 60.

Det falder uden for denne fremstillings rammer at foretage en historisk bedommelse af Laurids Skaus politiske virke og af $P$. Lauridsens og senere forfatteres vurdering heraf. Se herom indledningen til Laurids Skaus Brevveksling med politiske Venner i København, s. 9-17.

27. *København $19198 / 4$.

28. "Kobenhavn* 1919 15/4.

Opmærksomheden henledes på, at alle citater er gengivet med originalens retskrivning (også hvor der er tale om anvendelse af små bogstaver og bolle-å på den tid). 